\title{
PROBLEM ,SYTUACJI GRANICZNYCH” W UJĘCIU KARLA JASPERSA
}

Karl Jaspers, po studiach prawa i medycyny oraz po habilitacji z psychologii w r. 1913 na uniwersytecie w Heidelbergu, swoje zamiłowania skierował wyłącznie ku psychiatrii i analizie sytuacji duchowej współczesnego świata. Dał temu wyraz w swoim bogatym dorobku naukowym ${ }^{1}$.

Jako filozof Karl Jaspers należy do kręgu egzystencjalistycznego, obok P. Satre'a, G. Marcela, M. Heideggera i in. W nurcie tego prądu filozoficznego Jaspers stanowi jednak postać szczególną. Wszyscy egzystencjaliści zajmowali się i zajmują zagadnieniem egzystencji ludzkiej, ale czynią to w szerszym aspekcie. Przykładem tutaj może być M. Heidegger, dla którego problem egzystencji ludzkiej był tylko punktem wyjścia w jego refleksji filozoficznej. Dla Jaspersa natomiast, egzystencja ludzka stała się głównym przedmiotem ${ }^{2}$ takiej refleksji. Wychodził on bowiem z założenia, że skoro nad określonymi sytuacjami fundamentalnymi życia ludzkiego „filozofowie racjonaliści całkowicie zaniedbali" ${ }^{3}$ reflektować, wobec tego on może uważać się za upoważnionego do zajęcia się w sposób szczególny nimi, wyjaśniając je na drodze filozoficznej analizy.

\section{POGLĄD OGOLLY NA ,SYTUACJE GRANICZNE”}

Karl Jaspers w swym dziele pt. Psychologie der Weltanschauungen (1922) w rozdz. III, s. 229-280 wprowadza pojęcie ,sytuacji granicznych"

1 Psychologie der Weltanschuungen, Berlin 1922; Die geistige Situation der Zeit, Berlin 1931; Philosophie, t. 1-3, Berlin 1932; Die Schuldfrage, Zürich 1946; Vom europeischem Geist, München 1946; Der philosophische Glaube, München 1948; Vom Ursprung und Ziel der Geschichte, München, 1949; Die Atombombe und die Zukunft der Menschen. Politisches Bewusstsein unserer Zeit, München 1958; Philosophie und Welt. Reden und Aufsätze, München 1958.

2 Tatarkiewicz Władysław, Historia filozofii, Warszawa 1958, t. 3, 485.

3 Por. Dictionnaire de la philosophie, ed. Larousse, Paris 1964, 151. 
oraz daje ich szczegółowy opis ${ }^{4}$. Autor zakłada, że czytelnikowi pojęcie sytuacji jest dostatecznie znane. Wydaje się jednak, że powinno się je nieco bliżej określić. Potem dopiero wyjaśnimy pojęcie ,sytuacji granicznych" w ujęciu Karla Jaspersa.

Sytuacja oznacza położenie. Nas jednak nie interesuje jakiekolwiek położenie, lecz takie tylko, w którym znalazł się człowiek. Nadto, chodzi w tym wypadku o położenie aktualne, tj. takie, którego określone okoliczności człowiek sobie uświadamia i wobec których może on również przyjąć jakąś postawę. Toteż, na sytuację w ogólnym znaczeniu składać się będzie zawsze jakaś ,suma wpłyıwów zewnętrznych i świadomych reakcji na nie" 5 ze strony człowieka, którego one hic et nunc dotyczą. M. Pfliegler podkreśla słusznie, że sytuacją zajimujemy się na ogół wówczas dopiero, kiedy ona staje się aktualnym problemem ze względu na swoją krytyczność ${ }^{6}$.

Człowiek nigdy nie chce dla siebie tego, co mu się jawi jako przykrość, cierpienie, nieszczęście czy zagrożenie własnego życia. Czy potrafi on jednak trzymać każde cierpienie $\mathrm{z}$ dala od siebie? Pytanie jest retoryczne. W życiu bowiem istnieją sytuacje - uczy Jaspers - które z jednej strony związane są z człowiekiem jako takim, $z$ drugiej zaś są zarazem niemożliwe do uniknięcia ?.

Tego rodzaju sytuacje, układające się ,,wzdłuż granic naszego bytowania" 8 - jak się wyraża Jaspers - gdy są przez człowieka nie tylko uświadamiane, ale również osobiście doświadczane jako coś bezwyjściowego i ostatecznego, stanowią dla niego właśnie, ,sytuacje granic z n e", zwane też fundamentalnymi.

K. Jaspers nie daje, niestety, w swej „Psychologi” definicji słownej ,,sytuacji granicznych". Daje jedynie definicję rzeczową, opisową. Skła-

${ }^{4}$ K. Jaspers, Psychologie, 229-180. Por. także: K. Jaspers, Philosophie, t. 2. 203: Gramicznymi nazywam takie sytuacje, które polegają na przykład na fakcie, że zawsze jestem wplątany w jakąś sytuację, że nie mogę żyć bez walki i bez cierpienia, że nieuchronnie przyjmuję na siebie winę, że muszę umrzeć. One się nie przekształcają, lecz tylko zmieniają się w swoich przejawach; sprowadzone do naszej kondycji (Dasein), są ostateczne. Nie możemy sięgnąć ponad nie; w naszej kondycji niczego poza nimi nie widzimy. Są one jak mur, o który się obijamy, o który się potykamy. Nie jest w naszej mocy je zmienić, lecz tylko oświetlić, bez wyjaśnienia lub częściowo wypnowadzić z czegoś innego od nich. Są one wszystkie związane z samą naszą kondyicją.

5 Pfiegler Michael, Die religiöse Situation, Wien 1948, 17 n. Por. także n. t. sytuacji: G. Marcel, Od sprzeciwu do wezwania, Warszawa 1965, 294, pisze: „Dasein (sytuacja p. m.), tzn. tutaj, jako byt empiryczny znajduję się w sytuacjach, w których działam i które na mnie oddziałują".

${ }_{6}^{6}$ M. Pfliegler, dz cyt., 18. Por. także: Człowiek $w$ sytuacji, w: Tadeusz Tomaszewski, Psychologia, Warszawa 1977, 17-36.

7 K. Jaspers, Psychologie, 229. Por. także: G. Marcel, dz. cyt., 294: „Byt empiryczny jest bytem w sytuacji". Nigdy nie może wyjść z jednej sytuacji, nie wchodząc w inną sytuację".

8 K. Jaspers, Psychologie, 229. 
dają się na nią elementy, które dopiero razem wzięte, wypełniają pojęcie „sytuacji granicznych" 9 . Jaspers wymienia następujące cztery elementy:

1) ograniczoność natury ludzkiej,

2) nieuniknioność określonych układów negatywnych w życiu ludzkim,

3) świadomość własnej ograniczoności wobec owych określonych układów negatywnych, nie dających się uniknąć,

4) osobiste $\mathrm{i}$ faktyczne przeżywanie w życiu swoim owych określonych układów negatywnych.

Używając wyrażenia ,określone układy negatywne w życiu” mamy na myślli cztery szczegółowe ,sytuacje graniczne”, które wymienia K. Jaspers. Będzie o nich jeszcze mowa poniżej. W tym miejscu należy wyjaśnić, że swoją wspólną nazwę ,sytuacje graniczne" zawdzięczają one K. Jaspersowi.

Gdy chodzi o wspomniane wyżej elementy, składające się na pojęcie „sytuacji granicznych", to należy stwierdzić, że dwa pierwsze z nich mają charakter obiektywny, natomiast trzeci i czwarty wskazuje na subiektywną stronę ,sytuacji granicznych".

$\mathrm{Na}$ podstawie wymienionych czterech elementów, tworzących razem pojęcie ,sytuacji granicznych" w ujęciu Karla Jaspersa, można by podjąć próbę sformułowania słownej definicji, możliwie szerokiej, a mianowicie:

„Sytuacje graniczne”, są to określone układy negatywnych warunków życia ludzkiego, którymi człowiek czuje się głęboko zraniony wewnętrznie, ilekroć uświadamia sobie własną ograniczoność wobec nieuniknioności owych układów oraz gdy przeżywa je, nie tylko teoretycznie, ale także faktycznie jako coś absolutnie bezwyjściowego i ostatecznego".

Ograniczoność natury ludzkiej ma charakter bytowy i istotny. Tkwi ona w samej strukturze psychofizycznej każdego człowieka. Jest mu wraz $\mathrm{z}$ jego naturą po prostu dana. $\mathrm{Z}$ tej ograniczoności wynika również skończoność przymiotów człowieka, zarówno fizycznych (np. zdrowie, siła itp.), jak i psychicznych (np. rozum, wola, pamięć itp.).

Pewne sytuacje stanowią w życiu człowieka nie tylko absolutną g r an icę dla jego zdolności przystosowawczych i obronnych, lecz odznaczają się jeszcze tym, ż el nie dają się ominąć.

Są to właśnie owe ,sytuacje graniczne", wspomniane przez Karla Jaspersa, przeżywane zawsze przez człowieka jako wyjątkowo przykre cierpienie psychiczne. Jaspers wymienia cztery takie sytuacje:

1) walka, 2) śmi erć, 3) przypadek, 4) wina.

Przeżywanie ,sytuacji granicznych” zakłada pełn ą ś wi a d o mo ść

${ }^{9}$ K. Jaspers, Psychologie, 256 n. 
własnej ograniczności wobec zaistniałej komplikacji. Chodzi zatem nie o jakieś - mniej lub więcej - mdłe przeczucie tylko, że przykre położenie jest bliskie i nieuniknione, ale o pe w $\mathrm{n}$ oś ć. Wobec nieuchronnego zbliżania się którejś z wymienionych wyżej sytuacji, człowiek ma świadomość, że jest całkowicie bezradny. Wszystko bowiem, na czym w normalnych warunkach zwykł on się wspierać, 'w ",sytuacji granicznej” zawodzi i bywa bezsilne i nieskuteczne. Takiej świadomości nie mają w podobnych wypadkach tylko dziecko i człowiek nienormalny, u których poczucie rzeczywistego niebezpieczeństwa jest nierozwinięte. Dla zdania sobie sprawy z powagi ,sytuacji granicznej" potrzebna jest dojrzała świadomość oraz w pełni rozwinięte ,,ja" osobowe. Warto zaznaczyć w tym miejscu, że rozwój „ja” osobowego może wskutek znalezienia się młodej osoby w ,sytuacji granicznej" ulec pewnemu przyspieszeniu ${ }^{10}$.

Najgorszą rzeczą jest, że człowiek nie może - choćby chciał - na dalszą metę owych bezwyjściowych sytuacji sobie nie uświadamiać. Odsuwane na plan drugi lub spychane do podświadomości, będą one mimo to raz po raz powracały do poziomu świadomości, by data occasione, zakreślić grubą linią g r a n i ę dla możliwości obronnych i przystosowawczych człowieka.

Aby zdawać sobie sprawę, co znaczy dla człowieka „sytuacja graniczna”, trzeba znaleźć się w bezpośrednim polu jej oddziaływania. Jaspers mocno podkkreśla, że sama świadomość teoretyczna o tym, iż taki już jest los każdego człowieka, nie daje jeszcze właściwego wyobrażenia, co człowiek odczuwa, gdy się w tego rodzaju krańcowych warunkach sytuacyjnych naprawdę znajdzie.

W związku z tym należałoby wyjaśnić pewną trudność. Otóż, Jaspers powiada wyraźnie, że "tylko niewielu żyje w sytuacjach granicznych", tj. niewielu żyje $\mathrm{w}$ nich rzeczywiście. W związku z tym powstaje pytanie, jak powinno się to oświadczenie Jaspersa rozumieć? Wiadomo, że „sytuacje graniczne" są związane z naturą ludzką jako taką. Stanowią zatem prawo bezwyjątkowe, dotyczące każdego człowieka.

W odpowiedzi na tę trudność trzeba podkreślić, że nie każdy człowiek przeżywa ,sytuacje graniczne” jak faktycznie coś os ta teczneg o (das Letzte) ${ }^{11}$. Dzieje się tak z różnych przyczyn, zarówno wewnętrznych, jak i zewnętrznych.

Nie wszyscy ludzie także pozostają w bezpośrednim polu oddziaływania na siebie ,sytuacji granicznych". Stąd też, dla większości ludzi owe

10 Przykładem tutaj mogą być fakty, które o sobie zanotowała w swym „Dzienniku" Anna Frank. Zdaniem krytyków, wykazywała ona w chwili pisania "Dziennika" dojrzałość ponad swój wiek. Był to skutek przebywania autorkłi "Dziennika" przez ponad dwa lata w ,sytuacjach gramicznych" w czasie ukrywania się przed Gestapo w Amsterdamie, por. Dziennik Anny Frank, Warszawa ${ }^{2} 1957$.

${ }_{11}$ K. Jaspers, Psychologie, 229 oraz 251, 258, 267, 273. 
kwalifikowane sytuacje są w podwójnym sensie dla nich odległe: 1) we własnej świadomości, 2) w sferze czasu.

Nie zmienia to jednak samego faktu, samej bezwyjątkowej rzeczywistości. Co najwyżej, można mówić tutaj o jakiejś niepełności czy niezborności określonych warunków formalnych, składających się na faktyczną sytuację graniczną, gdy chodzi o daną jednostkę. Owa niezborność elementu świadomościowego i czasowego u niektórych ludzi decyduje jedynie o zmianach w subiektywnym odczuciu tej rzeczywistości. Obiektywnego faktu natomiast, dotyczącego „sytuacji granicznych" nie zmienia to $u$ nikogo $z$ ludzi. A zatem, wyrażenie Jaspersa, iż „tylko niewielu żyje w sytuacjach granicznych", nie należy rozumieć w ten sposób, jakoby niektórych $\mathrm{z}$ ludzi te sytuacje omijały w życiu. Nie znaczy to więc, że wielu ludzi „sytuacji granicznych” wcale nie przeżywa, lecz że wielu ludzi tych sytuacji jeszc ze nie przeżywało.

\section{POGLĄD NA SZCZEGOEOWE ,SYTUACJE GRANICZNE”}

Po zaznajomieniu się z ogólnym poglądem na "sytuacje graniczne" spróbujmy przyjrzeć się szczegółowym ich odmianom według tego, jak nam je wymienia $K$. Jaspers przede wszystkim w swojej „Psychologii” ${ }^{12}$, a także w innych swoich dziełach ${ }^{13}$. Te szczegółowe "sytuacje graniczne", to: walka, śmi erć, przypadek, wi na. Ten przegląd szczegółowych ,sytuacji granicznych" poprzedzimy wywodami Jaspersa n. t. ci erpienia, które towarzyszy wszystkim czterem odmianom ,sytuacji granicznych" ${ }^{14}$.

Jaspers zaraz na wstępie swoich rozważań n. t. „sytuacji granicznych”, tj. walki, śmierci, przypadku i winy podkreśla, że ich subiektywny aspekt charakteryzuje się tym, że są one przez każdego człowieka zawsze przeżywane w pryzmacie os obistego cierpienia. Stąd też - stwierdza Jaspers - jakkolwiek samo cierpienie, nawet wyjątkowo intensywne, nie jest jeszcze jedną odmianą ,sytuacji granicznych”, jest jednak wspólnym mianownikiem dla każdej z nich z osobna wziętej.

Człowiek przez bardzo intensywne życie, zwłaszcza w ramach aktywności, związanej $\mathrm{z}$ wykonywanym zawodem, może zapomnieć na jakiś czas lub zepchnąć na plan dalszy problem swoich egzystencjalnych cierpień. Sam Jaspers dokonał tego, że będąc od urodzenia nieuleczalnie chorym na Bronchiektases (termin polski: rozstrzenie oskrzeli), czyli chorobę połączoną $\mathrm{z}$ chroniczną niewydolnością serca, zapominał się $\mathrm{w}$ pracy

12 Tamże, 256-280.

13 Por. np. K. Jaspers, Philosophie, t. 2, 201-254.

14 K. Jaspers, Psychologie, 247-256. Por. także: G. Marcel, dz. cyt., 303-318. 
naukowej ${ }^{15}$. A jednak, ani on, ani nikt inny nie był i nie będzie w stanie zapomnieć o losie, jaki człowiekowi przypadł w udziale na świecie (das Elend des Daseins) ${ }^{16}$.

$\mathrm{Z}$ trwałym cierpieniem związana jest również refleksja nad antynomią, istniejącą na świecie. Jaspers przybliża nam niektóre z tych antynomii i wylicza je, np. krwawa walka między wszystkim, co żywe; niszczenie tego, co do niedawna jeszcze rosło; jakiś nieznośny ból, ciągle powracający; strata drogiej osoby; bezradność 'w obliczu cierpień najbliższych sobie osób; niszczenie kultury; wiele wartości bezmyślnie niszczonych, przy równoczesnej niemożności położenia temu kresu z naszej strony; chcieć a nie móc niczego zmienić na lepsze, np. w ciężkiej chorobie, w skrajnym ubóstwie, w dziedzicznym obciążeniu; świadomość tego, że popadam w postępującą chorobę umysłową; strach przed nieuniknioną a bliską już chorobę nieuleczalną i śmiercią; rozpacz w obliczu winy, od której nie sposób się wymówić, ani jej w jakikolwiek sposób także naprawić, doświadczanie bezsensowności przypadku itp. ${ }^{17}$.

W każdym z wymienionych 'wyżej przykładów antynomil zachodzi zawsze cierpienie, wywołane widokiem tego, co definitywnie przerasta siły człowieka, wobec czego jest się po prostu bezradnym i bezsilnym, co trzeba jednak - chcąc nie chcąc - cierpliwie znosić.

Pójdźmy obecnie nieco dalej i przypatrzmy się wraz z Jaspersem czterem szczegółowym odmianom „sytuacji granicznych":

W alka: Życie nie zostało człowiekowi zaofiarowane jako gotowy „,produkt do konsumowania”. Według wyrażenia Jaspersa jest ono żyw y m procesem (ein lebendiger Prozess) ${ }^{18}$, w którym wszystko, co potrzebne, musi być dopiero twardo zdobywane. To zaś oznacza w a $1 \mathrm{kę:}$ o warunki materialne do życia, o przyjęcie na studia, o mieszkanie, o stanowisko, o wolność i przekonania, o słuszne dla siebie prawa itd. Nawet we wnętrzu każdego człowieka odbywają się usitawicznie z apa s y ( $\alpha \gamma^{\prime} \omega_{\nu}$ ) pomiędzy racjami rozumowymi a nieaprobowanymi dynamizmami niższych kategorii ${ }^{19}$.

Walka dlatego jest „sytuacją graniczną" w rozumieniu K. Jaspersa, ponieważ jest koniecznością, nie dającą się uniknąć. Jest to tak dalece prawdziwe, że w wypadku nie podjęcia walki, człowiek schodzi na margines życia, a nawet - co gorsza - własne życie po prostu przekreśla. Nikt, oczywiśsie, nie chce walki jako powsizedniego zajęcia. Wszak jest

15 Por. Michał Mazur, Karl Jaspers - filozof prawdziwości, w: „Znak”, n. 183, wrzesień 1969, 1179-1202. Por. także: Aleksander Rogalski, Karl Jaspers, twórca filozofii pojmowanej jako aktywność praktyczna, w: Tegoż autora, Myśl i wyobraźnia, wyd. Pax, Warszawa 1977, 34-64.

$16 \mathrm{~K}$. Jaspers, Psychologie, 247.

17 Tamże, 248.

18 Tamże, 280. Por. także: G. Marcel, dz. cyt., 307-312.

19 K. Jaspers, Psychologie, 257-258. 
ona zawsze czymś przykrym i niepożądanym. Dodatkowa przykrość płynie stąd, że adwersarzem bywa zwykle drugi człowiek, który bądź nas atakuje, bądź się broni. Przykro człowiekowi, że inaczej być nie może, że już tak być musi w życiu ludzkim. Każdy bowiem chce przede wszystkim żyć a następnie wypełniać życie czymí znakomitym. Gdyby jednak zrezygnował $\mathrm{z}$ walki, tym samym musiałby się pożegnać z życiem, rozwojem, z dochodzeniem do życiowych rezultatów. Pozostaje zatem, smutna konieczność walki u człowieka, podobnie jak to bywa w przyrodzie: o byt, wzrost, nozwój, przewagę, a nawet o miłość drugiego czlowieka ${ }^{20}$.

Śmierć: Jest ona zawsze rzeczywistością jak najbardziej in dywi d u a ln ą, zarówno gdy się ją pojmuje jako proces, tzn. jakio u mi eranie (Sterben), jak i wtenczas, gdy patrzy się na drugi niejako jej akt, czyli śmierć biologiczną, oznaczającą definitywne zakończenie procesu umierania - z g on (Tod). „Moja śmierć - pisze Jaspers - nie może być przeze mnie doświadczona; nie ma doświadczenia bez jego przebycia" 21, mając na myśli śmierć biologiczną. Toteż, każdy przeżywa właściwie w pełni tylko własną śmierć, doświadcza swego umierania.

W procesie umierania można rozróżnić na podstawie najnowszych badań E. Kübler-Ross ${ }^{22}$ trzy nierówne czasowo stadia:

1) Doświadczanie tego, co z daleka zapowiada przyszłą śmierć, a więc: przebytte choroby, operacje, zapaści, strata bliskich osób itp. (trwać może nawet kilka lat),

2) Przeżywanie tzw. końcówki procesu umierania, na którą składa się co najmniej 5 faz (trwa to od kilku miesięcy do paru tygodni, czy też tylko do paru dni),

3) Przeżywanie śmierci klinicznej (trwa do $4 \mathrm{~min} .{ }^{23}$.

W każdej z powyższych trzech stadiów ciężko chory jest mniej lub więcej świadomy tego, co przeżywa. Jest zatem również w stanie opowiedzieć coś na ten temat swemu otoczeniu. Dotyczy to nawet śmierci klinicznej, z której umierający zdołał powrócić do świadomości.

Natomiast $\mathrm{z}$ tego, co człowiek przeżywa w 'związku ze swą śmiercią biologiczną (zwaną téz śmiercią metafizyczną), umierający niczego już nie opowie. Pozostanie to już na zawsze dla nas tajemnicą. Umarły wprawdzie wie, ,jak to jest", ale tę wiedzę zabiera on ze sobą. Jest to

20 Tamże, 257 n. Por. także tegoż autora, Philosophie, t. 2, 238. Por. także: G. Marcel, dz. cyt., 312, pisze, że ,nawet łączność w miłości przedstawia slę jako walka" (combat amoureuse).

${ }^{21} \mathrm{~K}$. Jaspers, Psychologie, 259-270. Por. także tegoż autora, Philosophie, t. 2, 222. Por. talkże: G. Marcel, dz. cyit., 301-306.

22 Por. Elisabeth Kübler-Rosis, Interviews mit Sterbenden, Stuttgart-Berlin 1977, $41-119$.

${ }_{23}$ Por. Raymond Mood, Life after Life, New York 1975. Tł. niem. Leben nach dem Tod, Hamburg 1977. Por. także: Mieczysław Pszon, Niezwykta opowieść o śmier$c i$, ,Tyg. Porwsz.", n. 44 (1977) 
już wyłącznie sprawą wiary odpowiedzieć na pytanie: Co dalej po śmierci? Toteż, filozofia na ten temat millczy.

Smierć jest niewątpliwie „sytuacją graniczną", tzn. ostateczną i bezwyjściową ${ }^{24}$. Współczesna medycyna stwierdza, że kres życia zakodowany jest $w$ genach ludzkich. Można bowiem przedłużyć jedynie okres starzenia się, ale nie kres wysuszania się ludzkiego organizmu.

Przypadek: „Zjawisko lub fakt, którego zaistnienie nie jest uważane za konieczne ze względu na określony ciąg przyczyn i skutków" nazywamy przypadkiem $\mathrm{w}$ znaczeniu filozoficznym ${ }^{25}$. Ma on to do siebie, że nie musi i nie powinien zajść, a tyllko się $\mathrm{zdarza}$. Ponieważ zaś przypadek jest niekonieczny, jest tym samym zawisze niepożądany, nieoczekiwany, bo i bezcelowy. Mówi się dlatego o tzw. „głupim przypadku" (Sinnlosigkeit) ${ }^{26}$. Mimo swej bezcelowości, przypadek spotyka jednak każdego człowieka. Nikt bowiem nie potrafi ustrzec się go w swoim życiu. W tej czy innej formie zdarza się on nawet najbardziej przezornym, ostrożnym.

Podobnie, jak wymienione wyżej odmiany "sytuacji granicznych", przypadek jest również $\mathrm{z}$ kategorii tzw. sytuacji fundamentalnych, czyli takich, w których człowiek umieszczony jest $\mathrm{n}$ a s t a łe. Jaspers określa to dobitnie słowami: „Cokolwiek byśmy pomyśleli, na granicy naszego bytu empirycznego (Dasein) i naszego wyobrażenia, wszędzie znajduje się przypadek" ${ }^{27}$. Przypadek jest od człowieka niezależny, związany $z$ jego naturą. I ta jego niezależność od aktów rozumu i woli człowieka stanowi o tym, że przypadek zalicza się do „sytuacji granicznych".

W in a: Nic tak głęboko nie wrzyna się w świadomość człowieka, jak to, że nie potrafi on wymówić się od jakiejkolwiek winy za swoje czyny, myśli, uczucia, decyzje ${ }^{28}$. Wina człowieka 'w jego życiu płynie stąd, iż mimo że zdaje sobie sprawę z popełnianych błędów - nie chce żyć tak zupełnie ,na czysto". Wprawdzie pojedyncza motywacja bywa niekiedy czysta. Jednakıwoż w tzw. wielkiej syntezie (całości), ze względu na konsekwencje, rzadkko jest ona tak całkowicie bez skazy. Rzadko, decyzja przynosząca nam korzyść, nie pociąga równocześnie czyjejś szkody. Zbyt często również na dnie indywidualnej motywacji kryje się egoizm, zazdrość, wygodnictwo, niesprawiedliwość itp. ${ }^{29}$.

Wina zaliczana jest do ,sytuacji granicznych", ponieważ i ona - jak widać - bywa dla człowieka sytuacją bezwyjściową, nie dającą się przez nikogo uniknąć.

24 K. Jaspers, Philosophie, t. 2, 203. Także tegoż autora Psychologie, 250.

25 K. Jasspers, Psychologie, 270.

26 Tamże, 248.

27 Tamże, 271 .

28 Tamże, 237; oraz 273-274. Por. także tegoż autora, Philosophie, t. 2, 203. Por. także G. Marcel, dz. cyt., 312 n.

$29 \mathrm{~K}$. Jaspers Psychologie, 274. 


\section{PSYCHICZNE REAKCJE W „SYTUACJACH GRANICZNYCH”}

Każda sytuacja życiowa, w stopniu, w jakim bywa przez człowieka uświadamiana, spotyka się $\mathrm{z}$ postawą reaktywną z jego strony. Jego inteligencja objawia się $\mathrm{m}$. in. w tym, że stać go na różną reakcję, w zależności od przeżywanego bodźca. Podstawowym warunkiem zareagowania na „sytuację graniczną" będzie zawsze najpierw uświadomienie sobie zagrożenia $z$ jej strony. Jaspers ujmuje to w następujących słowach: „Mogę wyjść z jakiejś sytuacji, tylko opanowując ją przez poznanie jej, tzn. gdy stanie się ona dla mnie przeźroczysta" ${ }^{30}$. Cel tych reakcji jest wszelako jeden i ten sam: przywrócić, zaćnwianą bezpośrednim zagrożeniem ze strony ,sytuacji granicznej”, homeostazę, tj. wewnętrzną równowagę psychiczną, objawiającą się jako tzw. dobre samopoczucie.

Omówimy zatem, reakcje psychiczne człowieka, zarówno na cierpienie, jak i na poszczególne odmiany ,sytuacji granicznych”, według tego, jak je opisuje K. Jaspers w cytowanych już wielokrotnie tutaj jego dziełach.

\section{Reakcja na cierpienie}

Według K. Jaspersa człowiek zwykł reagować na cierpienie w podwójny sposób: Albo uważa je za coś ni e os t a t e c z n e g o (nicht etwas absolut Letztes), albo za coś os t a t e c z ne g o (etwas absolut Letztes) ${ }^{31}$.

Gdy ktoś uważa cierpienie za coś ni e ostat ec znego (albowiem uważa, że jest wyjście $z$ niego) ${ }^{32}$, wówczas unika go lub też przez intensywną działalność stara się nie dopuszczać do siebie jakichkolwiek myśli o nim. Tak rozumiane cierpienie człowiek również $\mathrm{zwalcza}$, głównie przy pomocy środków medycznych. Jaspers podkreśla, że w „licznych przypadkach mniejszych cierpień" notuje się pomyślny skutek ${ }^{33}$. Ludzie o prymitywnym sposobie myślenia sądzą nawet, że medycyna poradzi sobie za jakiś czas ze śmiercią i nieuleczalną chorobą - referuje Jaspers ${ }^{34}$.

W niektórych kręgach kulturalnych człowiek usiłuje swoje cierpienia „odczynić" przez różnego rodzaju obrzędy czarodziejskie ${ }^{35}$.

Chrześcijanin wierzy w zasługującą wartość swego cierpienia, znoszonego z poddaniem się Woli Bożej. On także uważa swe cierpienie za coś nieostatecznego, ale jako środek do osiągnięcia szczęścia poza grobem. Do

30 K. Jaspers, Philosophie, 205.

31 K. Jaspers, Psychologie, 251; 263.

32 Dlatego m.in. Jaspers nie zalicza cierpienia do ,sytuacji granicznych", ponieważ można $z$ niego znaleźć jakieś wyjście, zwłaszcza przy dzisiejszym postępie w medycynie, por. K. Jaspers, Psychologie, 250.

${ }_{33}$ K. Jaspers, Psychologie, 250.

34 Tamże, 250 .

35 Tamże, $250 \mathrm{n}$. 
tego rodzaju stanowiska wobec cierpienia Jaspers odnosi się krytycznie. „Odwaga wobec śmierci - twierdzi on - jest prawdziwą odwagą tylko wtedy, gdy wyłąozone jest jakiekolwiek wyobrażenie czegoś ponad nią... wierzący traci sytuację graniczną" ${ }^{36}$. Traci zaś sytuację graniczną, ponieważ uważa cierpienie każde - nawet to, które prowadzi do ostatecznego zniszczenia organizmu (,,cierpienie jest częściowym zniszczeniem" — powie G. Marcel) ${ }^{37}$ — za coś nieostatecznego.

Gdy natomiast, ktoś pojmuje swoje cierpienie jako coś absolutnie ostatecznego, tj. jako granicę wszelkich swoich możliwości, zarówno pasywnych, jak i aktywnych, wówczas - uczy Jaspers - przestaje ono być dla cierpiącego jedynie jakimś fragmentem jego życia. Cierpienie organizuje mu jego życie, tworząc jednorodny obraz, w którym wszystkie ,kolory” w sposób konieczny przynależą do siebie. Jaspers powie, że w takim wypadku cierpienie nie jest szczegółem życia (nichts Einzelnes), lecz tworzy wraz z innymi przeżyciami egzystencjalnymi człowieka, pewną c ałość (gehört zur Totalität) ${ }^{38}$. Temu, który uważa cierpienie za coś ostatecznego, życie układa się jako uświadomione ograniczenie wszystkich możliwości obronnych, bo poddane sytuacji bezwyjściowej. Nic też dziwnego, że często o swym cierpieniu myśli, zastanawia się nad jego sensem, a w konsekwencji również nad sensem życia w ogóle.

Zdaniem Jaspersa, człowiek przyjmuje wobec cierpienia, jako øzegoś ostatecznego, jedną z czterech ,postaw cierpiętniczych”, czyli pogodzenia się z bezwyjściowością cierpienia ${ }^{39}$ :

1) Rezygnacja - człowiek, ani nie rozumie cierpienia, ani z nim nie walczy. Mimo to jednak ży'je, pracuje, mając świadomość z jednej strony, że cierpieć musi, a $z$ drugiej strony, że musi także żyć (niekiedy zaś sądzi, że pozostaje mu jeszcze tylko używać sobie).

2) Ucieczka od życia — skoro nie ma nadziei na jakąkolwiek zmianę na lepsze, nie ma też żadnego sensu do czegokolwiek w życiu dążyć. Najlepiej zatem, pożegnać się $\mathrm{z}$ życiem, $\mathrm{z}$ jego kruchymi radościami i... opaść w nicość (das Nichts anstreben), czyli zakończyć życie śmiercią samobójczą.

3) Heroizm - człowiek nie ucieka przed cierpieniem, wręcz przeciwnie, akceptuje życie, jako mające wartość samo w sobie, mimo że jest pełne nieuniknionego cierpienia. Stawia zatem na swoją wytrzymałość wg zasady: Im więcej cierpienia, tym więcej cierpliwości w życiu. Ze swym cierpieniem jest osamotniony. W heroicznej swej postawie akcentuje sensowność swojego życia, swego bytu empirycznego (Dasein).

\footnotetext{
36 Cyt. za G. Marcel, dz. cyt., 306.

37 Tamże, 306.

$38 \mathrm{~K}$. Jaspers, Psychologie, 251.

39 Tamże, 251/52.
} 
4) Postawa religijno-metafizyczna - trzy poprzednie postawy spotykalją się wg Jaspersa w tzw. doświadiczeniu religijnym, tj. w doświadczeniu Absolutu. Rezygnacja, ucieczka od życia i heroizm zostają uzupełnione o nowy wymiar, religijno-metafizyczny. Cierpienie pojmowane by'wa wówczas jako coś nieodłącznego od życia, coś nieuniknionego i w pewnym sensie ostatecznego. Człowiek musi cierpieć, ale znoszenie ciempienia ułatwia mu myśl o Tym, który w życiu pozagrobowym wszystko wyrównuje, a więc o nagrodzie, jaką sobie swą cierpliwością wysługuje. Czy postawie takiej odpowiada obiektywna rzeczywistość? Zdaniem Jaspersa, źródłem takiego poglądu są - niestety - tylko „paradokssalne projekcje mistycznych przeżyć" (paradoxe Projektionen von mystischen Erlebnissen) ${ }^{40}$. Jaspers sądzi bowiem, że projekcje takie rodzą się wskutek wyjątkowo intensywnych cierpień. Gdy człowiek widzi się $\mathrm{w}$ obliczu cierpienia $\mathrm{u}$ kresu swych możliwości obronnych, wówczas stwarza sobie „fikcję transcendentalną", co u Jaspersa oznacza „wyjście poza siebie", tj. poza granicę, zakreśloną przez własne wyobrażenie, chcenie i możliwość wykonania (Wissen, Wollen, Können) ${ }^{41}$. Oparcie się o taką „fikcję transcendentalną" - rozumuje Jaspers - nie dopuszcza w świadomości do powstania prawdziwej ,sytuacji granicznej" ${ }^{42}$. Nie dopuszczają do niej bowiem charakterystyczne przeżycia, jak: podniesienie na duchu, pogłębienie i wzbogacenie sensu doznawanego cierpienia.

Przypatrzmy się teraz reakcjom psychicznym człowieka w obliczu poszczególnych „sytuacji granicznych”, jak je opisuje Jaspers.

\section{Reakcja na sytuację walki}

Reakcja psychiczna na ,sytuację graniczną", jaką jest wa 1ka, z chwilą gdy się człowiek w niej znajdzie, może być różna:

1) Człowiek walki unika, mimo to, na dłuższą metę, nie udaje się to nikomu. Każdy ją w końcu przyjąć musi jako tzw. życiową konieczność.

2) Niekiedy człowiek przybiera sztuczną postawę w tym sensie, iż u daje, że nie uważa walki za coś ostatecznego, bądź też wmawia w siebie, że zdoła walki uniknąć. Pozostaje to $\mathrm{w}$ końcu bez skutku. Pod maską obojętności i źle skrywanego spokoju przeżywa taki wciąż rosnące napięcie.

3) Niektórzy ludzie karmią się walką. Oddają się jej dla samej satysfakcji, jaką w niej znajdują. Nawet praca sprawia im radość o tyle, o ile posiada charakter zapasów (agonal) ${ }^{43}$. W tych zapasach cho-

\footnotetext{
40 Tamże, 252.

41 Tamże, 252.

42 Tamże, 262.

เs Tamże, 259.
} 
dzi im jednak nie tyle o tryumf prawdy, co tryumf siły wobec napotkanej przeszkody.

4) Wreszcie niektórzy, aby nie popsuć sobie radości życia, nie wypowiadają się ani ,za”, ani „przeciw” walce. Przyjmują w tym zakresie jak najdalej idącą postaw ę neutral ną. Tymezasem, zapominają o tym, że walka jest nieuniknioną formą egzystencji (Daseinsforme) $\mathrm{w}$ dążeniu do 'wejścia $\mathrm{w}$ posiadanie wartości, nawet tam, gdzie idzie o milość (Kampf in der Liebe) ${ }^{44}$.

\section{Reakcja na sytuację śmierci}

Zdaniem Jaspersa, wobec śmierci bankrutuje zarówno wiara, jak i rozum ze swą argumentacją za nieśmiertelnością duszy ludzkiej ${ }^{45}$. Gdy człowiek znajdzie się już $\mathrm{w}$ bezpośredniej sytuacji śmierci, snuje swe rozważania Jaspers, odnajdzie w sobie co najwyżej jakieś resztki zdobytej kiedyś wiedzy o śmierci, której jeszcze nigdy nie przeżywał, resztki, pewnego nastawienia do niej (Einstellung). Gdy jednak sytuacja takowa naprawdę zaistnieje, najwłaściwszą - według Jaspersa - reakcją może być tylko rozwinięcie nowych sił ${ }^{46}$, aby proces ten dzielnie przeżyć. Tego rodzaju reakcja w obliczu bezpośredniego zagrożenia śmiercią, będzie zawsze wyrazem pozytywnego nastawienia do życia. Jednocześnie, owo nastawienie pozytywne nie będzie jednak wyprowadzone $\mathrm{z}$ idei nieśmiertelności duszy, ukazywanej $\mathrm{w}$ różnych formułach, tyleż wymyślonych, co nierealnych - konkluduje Jaspers ${ }^{47}$. Tymczasem jednak, ludzie zwykli reagować na sytuację śmierci w sposób odmienny od rozumowania jaspersjańskiego. Autor wylicza nam trzy, najczęściej spotykane, reakcje ${ }^{48}$ :

a) wyłącznie negatywne,

b) pozytywne w sensie buddystycznym,

c) pozytywne w sensie chrześcijańskim.

ad a) Reakcja wyłącznie negatywna wobec bezpośredniego zagrożenia śmiercią pojawia się wówczas, gdy człowiek dochodzi do wniosku, że wszystko, czego nauczyła go wiara, traci swe znaczenie. Na to miejsce już nic nie wchodzi. Na nic także zda się tutaj jakiekolwiek rozumowanie czy obmyślanie środków zaradczych. Zresztą, poza tym życiem - tłumaczy sobie człowiek - nie ma już niczego, żadna inna rzeczywistość się nie otwiera. Życie wypełnione jest chaosem i przedstawia się jako

${ }_{44}$ Tamże, 251. Por. także K. Jaspers, Philosophie, t. 2. 238, gdzie autor stwierdza: „Albo będę walkę afirmował (przyjmę ją p. m.), albo postaram się urzeczywistnić istnienie bez walki - to niemożliwe". Por. także: G. Marcel, dz. cyt., 312.

${ }^{45}$ K. Jaspers, Psychologie, 262.

46 Tamże, 262.

47 Tamże, 252; 262.

48 Tamże, 263-270. 
łańcuch przypadków. Nie istnieje również jakakolwiek odpowiedzialność pozagrobowa. Toteż, szczytem wszystkiego $w$ tej odmianie reakcji, jest negowanie wszystkiego, totalna negacja wszelkiego sensu, wszelkiej wiary transcendentnej.

ad b) Reakcja pozytywna w sensie buddystycznym wydaje się Jaspersowi mieć wiele słuszności w rozwiązywaniu problemu śmierci. W interpretacji buddystycznej życie pojmowane jest, nie jako coś absolutnie skończonego, tj. gdzie już naprzód wiadomo, kiedy nastąpi jego koniec i jakie jemu towarzyszyć będą okoliczności. Człowiek zmierza wg buddystów do jakiegoś bliżej nieokreślonego Absolutu, ale stale spotyka to tylko, co skończone. Nie neguje również śmierci jako ,,sytuacji granicznej", ani tego wszystkiego, co ją poprzedza.

Skąd zatem, człowiek czerpie siłę do niezałamywania się w swym życiu? Buddysta odpowiada: $\mathrm{Z}$ przekonania, w siebie wmawianego, że być może, istnieje jakieś inne jeszcze życie, pełne pokoju (ewige Ruhe), poprzedzone po śmierci wędrówką dusz z kolejnym wcielaniem się $\mathrm{w}$ inne byty (,das der Mensch ewig wiedergeboren wird") ${ }^{49}$.

ad c) Trzecią odmianą reakcji na problem własnej śmierci jest reakcja w sensie chrześcijańskim, czyli widzenie jej w świetle wiary $\mathrm{w}$ nieśmiertelność duszy ludzkiej oraz w świetle wiary w Boga, będącego Dobrem Najwyższym i sprawiedliwym Sędzią. Ta wiara każe patrzeć chrześcijaninowi na wszystko, co go $\mathrm{w}$ życiu spotyka, sub specie aeternitatis. Stąd, życie nie jest dla niego celem samym w sobie, ale tylko pewnym stadium na drodze do wieczności. Także śmierć nie jest czymś ostatecznym, lecz wskazuje na rzeczywistość, która otwiera się ponad nią.

K. Jaspers, przedsta'wiwszy powyższe trzy najczęściej spotykane reakcje na sytuację śmierci, wypowiada się z dużą sympatią o interpretacji buddyjskiej: „W tym życiu rozstrzyga się, czy człowiek osiągnie cel, jakim jest wieczny spokój" ${ }^{50}$. Nie aprobuje jednak obojętności wobec uroków życia i wobec zadań aktywnej działalności, jaką gdzie indziej wyznaje i zaleca ${ }^{51}$. Podobnie, nie aprobuje reakcji wyłącznie negatywnej, jako burzącej wszelki sens życia. W związku z omawianiem reakcji na sytuację śmierci, Jaspers ustosunkowuje się do interpretacji chrześcijańskiej tego problemu. Wiara w życie pozagrobowe, według Jaspersa, nie ma uzasadnienia, podobnie jak i wiara w Boga. To bowiem, co zwykło się nazywać dowodem rozumowym na nieśmiertelność duszy ludzkiej i na istnienie Boga, jest - jego zdaniem - jedynie pojęciem zbiorczym (Sammelbegriff) oraz opisem dróg, wynoszących duszę człowieka ponad granicę śmierci ku jakiemuś Absolutowi ${ }^{52}$. Rozum ludzki nie potrafi jednak, ani

\footnotetext{
49 Tamże, 264.

50 Tamże, 264.

51 Tamże, 227.

52 Tamże, 269.
} 
nieśmiertelności duszy udowodnić, ani jej zaprzeczyć (sie sind nicht beweisbar) ${ }^{53}$.

\section{Reakcje na sytuację przypadku}

Sposób reagowania człowieka na sytuację przypadku zależy od tego, czy chodzi o przypadek dla niego szozęśliwy czy nieszczęśliwy. Gdy idzie o pierwszą odmianę przypadku, człowiek nim dotknięty cieszy się raczej $z$ tego powodu. Po pewnym czasie nawet uważa, że na niego zasługiwał. Nic też dziwnego, że chętnie nań się zgadza. Gorzej jest z przypadkiem nieszczęśliwym. Człowiek widzi się bez racji poszkodowanym i w gorszej sytuacji, aniżeli wszyscy, których przypadek właśnie uszczęśliwił lub przynajmniej nie dotknął jakąś szkodą.

Najgorsze jest to, że na zły przypadek nie ma rady. Można by w tym miejscu postawić pytanie: Jak człowiek ustosunkowuje się do sytuacji przypadku? Jaspers twierdzi, że reakcja ta nie może być ametafizyczna, czyli najcześciej człowiek próbuje odkryć w przypadku jakiś nieempiryczny związek przyczynowy (np. szczęśliwa gwiazda, los, kaprys Boga itp.) ${ }^{54}$. Wspólnym mianownikiem dla wszystkich reakcji na sytuację przypadku jest to, że człowiek zawsze starał się ją przezwycieżyć, doszukując się $\mathrm{w}$ niej jakiegoś sensu, który gdzieś powinien tkwić. Nigdy człowiek nie poddaje się biernie sytuacji przypadku, lecz stara się wciąż o to, by go uniknąć. Jaspers sądzi, że najwłaściwszą reakcją na bezsens „,głupiego” przypadku powinno być poddanie się zdrowemu pędowi życiowemu (des lebendigen Impulses) pchającemu człowieka do życiowej aktywności ( $A k-$ tivität des Daseins) ${ }^{55}$. W rzeczy samej, wielu tak właśnie czyni.

Dzięki tej aktywności to, co w ,sytuacji granicznej”, jaką jest przypadek, jawi się jako bezsensowne, zostaje w dużej mienze stępione i złagodzone. Mimo że człowiek staje się często ofiarą przypadków, potrafi on znajdować radość i zadowolenie w swej aktywności zawodowej i w innych jeszcze zajęciach. Ta wieloraka aktywność daje mu pewne oparcie (Halt) w życiu, chociaż byłby bardziej zado'wolony, gdylby — na drodze przypadku - dostała mu się w udziale inna płeć, inna rasa, inna narodowość ${ }^{56}$.

Mówiąc o różnych reakcjach na przypadek, Jaspers ma na myśli oczywiście - te sytuacje, które w swym źródle były przypadkowe, w swych skutkach natomiast $\mathrm{n}$ i eod w racalne (das absolut Letztes ${ }^{57}$ ), jak np. przypadkowo wynikłe trwałe kalectwo, w którym trudno również dopatrzeć się czyjejś winy itp.

53 Tamże, 269.

54 Tamże, 272.

55 Tamże, 272.

56 Tamże, 273.

57 Tamże, 274. 
Reakcja na sytuację winy

Jaspers wymienia następujące reakcje możliwe na sytuację winy, od której człowiek nie potrafi się tak zupełnie wymówić, ponieważ zaciąga ją, albo jako autor czynu, albo jako odpowiedzialny za złe skutki swego działania, albo wreszcie jako ten, który prędzej czy później, kazi swoje postępowanie jakąś niewłaściwą pobudką ${ }^{58}$ :

1) Niektórzy ludzie mniemają, że po prostu muszą czynić źle, ponieważ urodzili się „diabłami” 59 (fatalizm p. m.). Inni świadomie czynią źle w pierwszej jak gdyby fazie, by potem podejmować próby poprawienia się. Jeśli im się to nie udaje, dochodzą do przekonania, że są przeznaczeni do czynienia źle, że urodzili się, aby być ludźmi złymi (Prädestination). Stąd, w myśl zasady dualizmu jedni będą zawsze $\mathrm{z}$ konieczności czynili dobrze, inni zaś źle.

2) Gdy chodzi o chrześcijanina, to ma on możność uiciec się po zaciągnięciu winy do Boga, gotowego mu zawsze przebaczyć. Począwszy od starożytności chrześcijańskiej nauka o usprawiedliwieniu znosi antynomię grzech-łaska. Czy jednak czyni to całkowicie? Niestety, pozostanie zawsze pewne napięcie między łaską, która oczyszcza, a wolną wolą, która odciąga człowieka ku grzechowi, a ten zżyma się równocześnie przeciwko „straszliwemu imperatywowi kategorycznemu” (I. Kant), zmuszającemu do tego, by stosować się do powszechnie przyjętego prawa etycznego ${ }^{60}$.

3) Skoro świadomość winy staje się w życiu jednostki sytuacją trwałą, tzn. ostateczną, nie dającą się w żaden sposób przezwyciężyć, rodzi się w człowieku ,kompleks biednego grzesznika" (Armesünderbewusstsein) ${ }^{16}$. Z tego rodzaju świadomością żyjąc, człowiek albo z tego powodu cierpi, bądź też skłania się do prowadzenia życia swobodnego, sprzecznego z zasadami moralnymi (halb leidend, halb genissend) ${ }^{62}$.

\section{W N I O S K I}

Powyższa prezentacja teorii Karla Jaspersa, dotyczącej „sytuacji granicznych", jest zaledwie jej szkicem, opartym na niektórych ważniejszych jego dziełach oraz innych autorów. Toteż, w tym miejscu przychodzi na myśl to, co Gabriel Marcel napisał na zakończenie swoich uwag o „sytuacjach granicznych”: „Przedstawiam te uwagi z pewną nieśmiałością, ponieważ myśli Jaspersa nie poddałem jeszcze integralnemu badaniu" ${ }^{63}$.

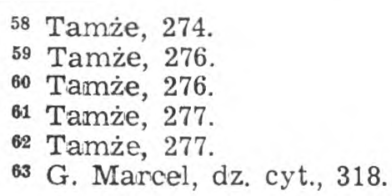


Wszelako to, co nazwaliśmy szkicem, daje pewne ogólne o wspomnianej teorii K. Jaspersa wyobrażenie.

Wypada na zakończenie wypunktować niektóre wnioski:

1) „Sytuacje graniczne” stanowią w życiu rzeczywistość związaną z ludzką naturą, ,albowiem, doświadczać sytuacji granicznych i istnieć, to jedno i to samo" ${ }^{64}$ - stwierdza Jaspers. Jest to rzeczywistość niezależna od tego, czy ją sobie ktoś uświadamia, czy nie. Kto nad „sytuacjami granicznymi" reflektuje, ten sobie uświadamia ich bezwyjściowość. Kto zaś ponadto znajduje się $\mathrm{w}$ polu ich bezpośredniego działania, ten bardzo głęboko cierpi.

2) Żadna $z$ sytuacji granicznych nie może byó. w żaden sposób usunięta i rozwiązana, ani przez refleksję, ani przez Nziałanie. Zdaniem Jaspersa, może ona jednak być opanowana, ale tylko poprzez zdanie sobie sprawy z niej. Innymi słowy, „można ją oświetlić, jednak bez jej wyjaśnienia" ${ }^{65}$.

3) Kto uważa „sytuacje graniczne” za coś ostatecznego, ten stara się być bardzo aktywnym w rozwijaniu swoich możliwości oraz w ulepszaniu świata. Kto zaś uważa ,sytuacje granicrne” za coś nieostatecznego, lecz mającego jedynie charakter stadium przejściowego, ten wg Jaspersa odczuwa obniżenie swego zapału i wykazuje osłabione zaangażowanie w twórczej aktywności ${ }^{66}$.

4) Chociaż ,sytuacje graniczne” można tylko - jak się wyraża Jaspers — „oświetlić bez wyjaśnienia" ${ }^{67}$, to jednak, celem ich praktycznego przezwyciężania, należy - zdaniem Jaspersa - - w swoim życiu opowiedzieć się za a kty w o ścią, stawiającą sobie za cel możliwie wszechstronny rozwój osobowościowy i społeczny w dostępnym sobie zakresie. Owa aktywność pozostaje w służbie życia, pojętego zawsze jako proc e s ${ }^{68}$.

5) Trudności, jakie Jaspers napotykał w rozwiązywaniu problemu nieśmiertelności duszy ludzkiej, czy człowieka w ogóle, rzutowały niewątpliwie na jego teorię o ,sytuacjach granicznych". Biadał nad tym G. Marcel, pisząc, że Jaspers „,w pogardliwy sposób v"ystępuje przeciwko wszelkiej idei nieśmiertelności" 69. W jednym z páźniejszych swoich dzieł ${ }^{70}$ Jaspers tylko częściowo zrewidował swe stanowisko, przypisując nieśmiertelność człowiekowi, ale tylko w sensie przenośnym: „Jesteśmy śmiertel-

\footnotetext{
64 K. Jaspers, Philosophie, t. 2, 204.

65 Tamże, 203; 205.

66 K. Jaspers, Psychologie, 251/52.

67 K. Jaspers, Philosophie, t. 2, 203.

68 K. Jaspers, Psychologie, 227; 248; 280.

69 G. Mancel, dz. cyt., 317.

$70 \mathrm{~K}$. Jaspers, Die Atombombe, 395.
} 
ni, o ile nie kochamy, kiedy zaś kochamy, wówczas stajemy się ni ésmier telni" (p. m.) ${ }^{71}$.

Karl Jaspers był przez całe swoje życie człorwiekiem o słabym zdrowiu. Ktoś wyraził się, że Jaspers musiał żyć przez całe lata „,w warunkach ciągłego stanu wyjątkowego", a przez okres hitleryzmu jego bytowanie było „egzystencją w sytuacji granicznej” 72. Mimo to, Jaspers dożył 86 lat (zmarł 26 II 1969). Można powiedzieć, że w myśl wyznawanej przez siebie teorii o aktywności, zdołał życie swoje podtrzymywać nieznużoną pracą, o czym świadczy jego dorobek naukowy opublikowany i będący jeszcze w rękopisach ${ }^{73}$.

$\mathrm{Na}$ pytanie, w jakim stopniu Jaspers posunął naprzód swoje dociekania w dziedzinie problematyki nieśmiertelności człowieka, trudno jest jednoznacznie odpowiedzieć. Niejedno z pewnością odkryją nam jeszcze jego inedita. W wydanym w r. 1935 studium, pt. Rozum i egzystencja, pisał heidelberski filozof: „To, że umysł filozofujący nie zadowala się swoją prawdą i że nie zamyka się w tym zadowoleniu, oznacza, że (...) stał się otwarty na to, co nim nie jest" ${ }^{74}$. Można zatem mieć nadzieję, że jego umysł, otwarty do końca na prawdę, zdołał sobie z tym trudnym problemem nieśmiertelności ostatecznie poradzić.

\section{DAS PROBLEM DER GRENZSITUATIONEN NACH KARL JASPERS}

\section{$\mathrm{Zus}$ a m menfassung}

Karl Jaspers (1883-1969) in seinem Werk "Psychologie der Weltanschauungen” (1922, zweite Auflage) hat uns seine Theorie von den Grenzsituationen deutlich dargestellt. In seinem anideren Werk „Philosiophie” (1932, Bd. II, K. VII, S. 201-254) und noch in vielen anderen seimen Werken, hat er die Theorie von den Grenzsituationen reichlich erläutert. Es handelt sich um vier fundamentale Arten von menschlichen Lebenssituationen und zwar: Kampf, Told, Zufall, Schuld. Mit dem Erlebnis der Grenzsituationen ist immer ein sehr tiefes Leiden verbunden. Trotzdem erklärt Jaspers - kann man es nicht als noch eine Art von den Grenzsituationen, fünfte etwa, ansehen. Aus dem Leiden, mag es noch so schrecklich sein, gibt es bei heutigem Fortschritt in der Medizin, immer noch einen Ausweg für den heimgesuchten Menschen. In den Grenzsifuationen aber, gibt es schon keinen Ausweg mehr und jeder Rettungsversuch bleibt auch immer zwecklos.

In seinem Lelben reagiert der Mensch auf die Grenzsituationen, die ihn unmittelbar getroffen haben, auf verschiedene Weise. Seiner Weltansichauung gemäss und auch dem, was der Mensich als sein höchstes Wert im Leben amstrebt, rea-

71 Tamże, 395

72 A. Rogalski, dz. cyt., 39; 51.

73 Według A. Rogalskiego, nie opublikkowana spuścizna Jaspersa obejmuje 25 tys. listów i ok. 35 tys. kart rękopisów, por. tegoż autora, dz. cyt., 59.

74 P.or. K. Jaspers, Vernunft und Existenz, München 1935, 121. 
giert er auf die Grenzsituationen, entweder mehr aktiv oder mehr passiv. Um einer vollständigen Verzweiflung und Depression zu entgehen - lehrt Jaspers sollte man vor allen Dingen an kein höchstes Wert, das von einer transzendentaler Herkunft wäre, glauben, da dies immer mit einer gewissen Entmutigung und mit einem Entkraften verbunden sei. Das höchste Wert für jeden Menschen ist - nach Jaspers - schlechterdings, das Leben selbsit. Damit ist aber kein rein biologisches Leben nur gemeint, sondern immer das Leben als ein Prozess, und zwar, vor allem psychischer Art.

So gesehen, wird das Leben eines jeden Menschen zu einem sehr harten Kampf um die Aneignung der einzelnen Werte. Eine ständige und möglichst intensive Aktivität, angesilchts des Factum der Grenzsituationen - meinte Karl Jaspers dürfte für eine beste Reaktion angesehen sein.

Jaspers lebite nach seinem Prinzip von der Aktivität. Es ist nicht ausgeschlossen, dass er sein hohes Lebensalter dieser Aktivität zu verdanken hat. 